\title{
The Relationship Between Leverage and Household Spending Behavior: Evidence from the 2007-2009 Survey of Consumer Finances
}

\author{
Karen Dynan and Wendy Edelberg
}

\begin{abstract}
Some recent studies suggest that high levels of household debt and leverage have contributed to the relatively sluggish growth of consumer spending in the past few years (Dynan, 2012; Mian, Rao, and Sufi, 2013). However, this conclusion has not been widely accepted because of the empirical challenges associated with identifying the relationship amid the dramatic and complicated changes in the household economic environment during the Great Recession and subsequent slow recovery. Leverage may indirectly influence spending by increasing borrowing constraints, impeding refinancing, and raising the likelihood that a household will face future borrowing constraints. Leverage may directly influence spending simply by making some households uncomfortable with their leverage compared with some behavioral benchmark. The authors use the 2007-09 Survey of Consumer Finances panel to explore these issues. They find that highly leveraged households were more likely to report cutting back their spending in 2009, even after controlling for other factors expected to influence spending, such as changes in income and wealth. In analyzing that relationship, the authors find evidence that leverage influenced household spending through several channels. (JEL E21, E44, E51)
\end{abstract}

Federal Reserve Bank of St. Louis Review, September/October 2013, 95(5), pp. 425-48.

$\mathbf{T}$ he recovery in U.S. consumer spending following the Great Recession was unusually weak by historical standards. In the first 12 quarters following the business cycle trough in June 2009, consumer spending's post-recession contribution to the cyclical strength in gross domestic product (GDP) was just over half of its historical average since World War II (Figure 1). The lackluster gains probably were due in part to developments among the con-

Karen Dynan is the Robert S. Kerr Senior Fellow at the Brookings Institution and currently on leave at the U.S. Treasury Department serving as a counselor to the secretary. Wendy Edelberg is assistant director for macroeconomic analysis at the Congressional Budget Office. The authors thank Neil Bhutta, Brian Bucks, Daniel Cooper, John Krainer, conference participants at the Federal Reserve Bank of St. Louis, and seminar participants at Washington University in St. Louis and the Federal Reserve Bank of New York for helpful comments. This paper was prepared for presentation at the symposium, "Restoring Household Financial Stability after the Great Recession: Why Household Balance Sheets Matter," sponsored by the Federal Reserve Bank of St. Louis and Washington University in St. Louis, February 5-7, 2013.

() 2013, The Federal Reserve Bank of St. Louis. The views expressed in this article are those of the author(s) and do not necessarily reflect the views of the Congressional Budget Office and/or members of its staff, the Federal Reserve System, the Board of Governors, or the regional Federal Reserve Banks. Articles may be reprinted, reproduced, published, distributed, displayed, and transmitted in their entirety if copyright notice, author name(s), and full citation are included. Abstracts, synopses, and other derivative works may be made only with prior written permission of the Federal Reserve Bank of St. Louis. 


\section{Dynan and Edelberg}

\section{Figure 1}

\section{Contribution of Real Personal Consumption Expenditures to the Cyclical Variation in Real GDP Following Recessions}

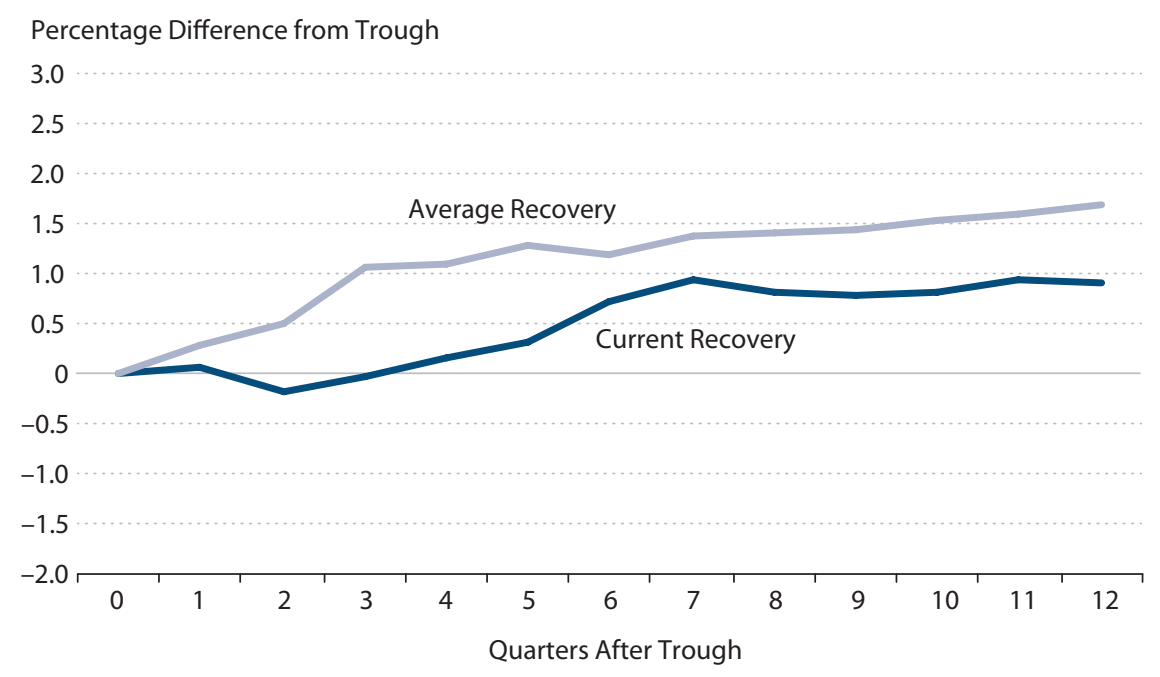

NOTE: Percentage difference from trough as a ratio of potential GDP.

SOURCE: Congressional Budget Office (2012), Figure 3.

ventionally accepted determinants of consumption_including wealth losses, weak income growth, limited availability of credit, and a more uncertain and pessimistic outlook for future income. However, recent research highlights another factor that may have dampened consumption: the high levels of household debt and leverage produced by the credit boom and subsequent asset price bust. For example, Dynan (2012) found that highly leveraged homeowners had substantially larger declines in spending between 2007 and 2009 than other homeowners, despite smaller changes in net worth. Similarly, Mian, Rao, and Sufi (2013) found that the response of retail sales to declines in wealth during the housing bust was more pronounced in counties with higher household leverage than elsewhere.

Further study of the relationship between leverage and consumer spending is needed, as the view that debt can independently weigh on consumption has not been widely accepted. Some analysts have argued that the empirical evidence is unpersuasive (Pence, 2012, and Cooper, 2012). In addition, the traditional models used by economists suggest that debt does not exert an independent influence on consumption - there is merely a positive and endogenous relationship because debt represents a means to finance spending that is spurred by other factors. However, going beyond these models reveals several reasons why high debt might have held back consumption. First, some households may have been forced to reduce their consumption because their high levels of debt relative to assets prevented them from obtaining any further credit needed to finance their desired spending. Second, some households may have spent less than they otherwise would have because high leverage prevented them from raising their discretionary monthly 
cash flow by refinancing their mortgages with lower-rate loans. Third, highly leveraged households may have become more uncertain about future credit availability, leading them to cut consumption to decrease leverage. Fourth, some households may target a given level of debt relative to their assets. If recent events pushed leverage above households' target ratios (and possibly simultaneously lowered households' target ratios), these households might have chosen to pare consumption to pay down debt.

The lack of consensus to date on the linkage between leverage and consumption largely reflects the empirical challenges associated with identifying the relationship amid the dramatic and complicated changes in the economic environment households faced in recent years. However, some further light can be shed on these issues through analysis of the 2007-09 Survey of Consumer Finances (SCF) panel. The panel consists of the regular 2007 SCF cross section, which contains comprehensive balance-sheet data for a representative (after weighting) sample of U.S. households, combined with information from a limited follow-up of the same households two years later. Importantly for our purposes, the follow-up included a rich set of attitudinal questions, providing an abundance of information about changes in households' economic situations and behavior over the 2007-09 period in addition to some insight into their plans for the future.

Our primary empirical approach is to examine how behavior, experiences, and future plans vary across households with different amounts of debt relative to their assets. The SCF panel provides information about how balance sheets changed over the period. We can use that information to control for the effects of factors correlated with high debt but expected to have their own influence on household spending behavior, which might otherwise complicate the interpretation of the results. Such factors include changes in respondents' net worth and income. In brief, the data corroborate earlier evidence that leverage weighs on consumption outside the usual correlation between leverage and consumption implied by the wealth effect. In particular, leverage appears to have an indirect effect on consumption, as higher leverage is clearly associated with reduced access to credit and a lower propensity to refinance a mortgage. In addition, we find that highly leveraged households showed a more pronounced increase in their precautionary concerns, which should imply lower household spending. Our results cannot determine whether this effect of leverage on spending is indirect (through the relationship between leverage and expectations of future access to credit) or direct (through high leverage simply making households feel uncomfortable or vulnerable in some more general way).

\section{LITERATURE REVIEW}

The dramatic developments in mortgage and consumer credit markets over the past few years produced a revival in the literature on household debt. Much analysis has been done on how households accumulated so much debt in the lead-up to the financial crisis and why household delinquencies and defaults subsequently soared. A full review of these studies is beyond the scope of this article, but notable contributions include those of Mayer, Pence, and Sherlund (2009); Foote et al. (2010); Bhutta, Dokko, and Shan (2010); and Keys et al. (2010).

Only a few studies to date have directly linked high household debt to real economic activity. Using data from the Panel Study of Income Dynamics (PSID), Dynan (2012) showed that spend- 


\section{Dynan and Edelberg}

ing by highly leveraged households fell more sharply between 2007 and 2009 than would be expected based on other factors affecting these households, including their decline in wealth. The noisy household-level data used by Dynan did not allow for precise estimates of the effect of excess household debt on the economy as a whole, but her point estimates implied a fairly modest impact. Cooper (2012) obtained similar findings at the household level using the PSID. 1 Using novel estimates of consumption and wealth at the county and zip code levels, Mian, Rao, and Sufi (2013) concluded that the marginal propensity to consume out of wealth was higher among households with more leverage than among other households.

The previous studies most closely related to the question of why leverage may be restraining consumption are those that use credit bureau data to examine why aggregate household debt has fallen in recent years. Many of the factors explaining this trend presumably also affect spending. The findings from this research approach are somewhat mixed; different studies underscore the importance of different factors. For example, Brown et al. (2013) find that defaults, morerestrictive lending conditions, and voluntary steps to reduce debt all played a role between 2008 and 2012. Bhutta (2012) presents evidence suggesting that reduced new borrowing was more important than defaults in explaining the decline in debt between late 2009 and late 2011. Demyanyk and Koepke (2012) conclude that the reduced rate of new household borrowing since the crisis primarily reflects a decreased appetite for debt rather than an unwillingness by banks to lend.

\section{OUR APPROACH}

The simplest theoretical models of consumer spending offer little guidance about whether high leverage might have restrained consumption during the recession and recovery and, if so, through what channels. In the most basic model, consumer spending, $C$, is a function of wealth, $W$, and expected lifetime (or "permanent") income, $Y$ :

$$
C=C(W, Y)
$$

Consumer spending is predicted to increase with higher wealth and income. Debt does not play a direct role in these models, but it could play an indirect role by means of the wealth effect (the positive relationship between consumption and wealth predicted by the model). In principle, because wealth equals the difference between assets, $A$, and debt, $D$, an exogenous increase in debt could lower wealth and, in turn, result in lower consumption. However, debt does not generally change exogenously. Rather, because it serves as a means to finance spending, debt tends to rise and fall endogenously as consumption rises and falls in response to movements in the traditional determinants of consumption.

Note, too, that the wealth effect associated with an exogenous movement in asset prices will mechanically produce a relationship between consumption and leverage, $L$, when leverage is defined as follows:

$$
L=\frac{D}{A} .
$$


In particular, if asset prices fall, wealth will fall and lead to a decline in consumption. The decline in asset prices will simultaneously produce an increase in leverage such that a negative correlation between consumption and leverage could be observed. A key point, however, is that the increase in leverage is not the driving force behind the decline in consumption in this case. Indeed, an increase in consumption as the result of an increase in expected lifetime income could be financed by an increase in debt. In that case, a positive correlation between consumption and leverage could be seen.

Richer specifications of the consumption function may include a role for interest rates, $r$; income uncertainty, $\sigma^{Y}$; borrowing constraints, $B$; cash flow (the net of flows in from monthly income and flows out from expenses previously obligated such as taxes and payments to service existing debt); and expected borrowing constraints, $B^{\exp }$ :

$$
C=C\left(W, Y, r, \sigma^{Y}, B, \text { cashflow }, B^{e x p}\right) .
$$

Such consumption functions offer additional channels through which debt and leverage can indirectly affect spending. To begin, a change in leverage can alter the degree to which a household faces borrowing constraints. We know that when lenders are deciding whether to extend a loan, they consider the losses they would incur if the borrower stops making payments. For example, a lender would be more reluctant to extend a second mortgage to a borrower with a highly leveraged primary mortgage. In the case of borrower default, the lender would be less likely to recover the full amount of the second mortgage after the proceeds from selling the home are used to cover the first mortgage. More generally, the role of leverage in determining borrowing constraints can change over time. Changes in economic and financial conditions may lead lenders to become more or less conservative in the benchmarks used to assess a prospective borrower's leverage or debt burden such that previously acceptable levels become unacceptable (and vice versa). $\underline{2}$

In a related manner, leverage may be indirectly linked to consumption through its influence on a household's ability to refinance its mortgage. When interest rates drop, many borrowers seek to refinance their mortgages to lower-rate loans to reduce their required mortgage payments. Just as lenders are reluctant to issue new debt to highly leveraged borrowers, a borrower's high leverage makes lenders reluctant to issue a new mortgage with a lower interest rate to replace an existing mortgage with a higher rate. $\frac{3}{}$

A household's inability to refinance because of high leverage means the household is denied two related benefits that might have motivated or allowed the household to spend more. First, refinancing at a lower interest rate lowers the total cost of servicing the debt, effectively increasing a household's wealth. As the simplest model of consumer spending shows, higher wealth typically increases spending. Second, a household's monthly cash flow is improved because less money is required to service the mortgage. Cash flow is likely a strong predictor of spending for households with low financial assets and an inability to increase their debt.

Finally, the model described by equation (3) allows leverage to have an indirect effect on consumer spending through its influence on households' expectations of access to credit in the future. Some households may want the option of future borrowing to avoid a sharp drop in con- 


\section{Dynan and Edelberg}

sumption in the face of unexpected income disruptions. All else equal, the higher a household's current leverage, the higher its expected future leverage and the more likely it is to face borrowing constraints in the face of such circumstances. Highly leveraged households may feel particularly vulnerable to future borrowing constraints if they are already straining to make large required debt payments and/or the rate of job loss is elevated, leaving them at high risk of impaired credit records through delinquency. ${ }^{4}$ Households may also worry that future unexpected events in credit markets, such as another financial crisis, could tighten their access to credit at a given level of leverage. Thus, even if highly leveraged households do not face immediate borrowing constraints, precautionary concerns related to the possibility of future constraints may lead them to pare back consumption to pay off debt or build up assets and, in turn, reduce leverage. $\underline{5}$

An even broader model of consumer spending might allow for a direct relationship between leverage and spending, in addition to the indirect relationships in equation (3). Some households may simply be uncomfortable with levels of leverage that exceed a particular behavioral benchmark. For example, households may feel stigmatized or vulnerable if their mortgage exceeds the value of their home such that they are "under water" on their loan. In this case, the consumption function might look like

$$
C=C\left(W, Y, r, \sigma^{Y}, B, \text { cashflow, } B^{e x p},\left(L-L^{*}\right)\right),
$$

where $L^{*}$ is the target level of leverage. In this specification, a higher level of leverage or a lower target level of leverage would directly dampen consumer spending. Note that households, like lenders, might change their benchmarks for what they consider an acceptable level of leverage as economic conditions vary over time. For example, the dramatic developments from 2007 to 2009 could have induced households to lower their target leverage ratio.

Using the 2007-09 SCF panel, our empirical analysis attempts to isolate the predictive relationship between leverage and consumer spending over this period. The question of whether leverage has restrained consumer spending in more recent years is an interesting one. However, because of data limitations, our evidence relates primarily to the period directly following the onset of the financial crisis and recession, when households were highly leveraged by historical standards and real (inflation-adjusted) consumer spending was generally falling.

We present new evidence on the relationship between leverage and spending that endeavors to set aside the mechanical correlation between increases in leverage and decreases in consumption resulting from the wealth effect. Instead, we look for evidence that leverage independently restricted consumption through the channels described previously by (i) increasing borrowing constraints, (ii) impeding refinancing, (iii) raising the likelihood that a household will face future borrowing constraints, or (iv) simply making some households uncomfortable with their leverage compared with some behavioral benchmark. Such relationships may have been underappreciated before the recession, partly because the United States had not experienced an episode of widespread very high leverage in recent history. Or, the relationships may have changed as a result of the recession and financial crisis. 
One limitation of our analysis is that it is difficult to empirically distinguish the role of leverage from that of debt service. Both are functions of the level of debt and thus are fairly highly correlated across households. In addition, lenders and households may avoid new debt (thus constraining household spending) because of high debt service obligations. For example, lenders make underwriting decisions based in part on the relationship between debt service obligations and income, which informs a household's ability to service new debt. Moreover, just as leverage jumped for many households during the recession because of the decline in asset values, so also might have their current and expected debt service "burdens" (the share of household income used for required debt payments) because of weak current income and dimmer prospects for future income.

\section{DATA}

\section{The 2007-09 SCF Panel}

Our analysis uses data from the 2007-09 SCF panel. The SCF is primarily a triennial crosssectional survey of about 4,000 households conducted by the Board of Governors staff of the Federal Reserve System. The SCF measures very detailed information on households' finances, demographics, attitudes, and other characteristics. In 2009, the Board of Governors reached out to the 2007 survey respondents to resurvey them; the response rate was nearly 90 percent. The panel dataset released to the public contains data from 3,862 households. Detailed information about the panel dataset is available in Kennickell (2011).

Our baseline analysis uses the full SCF panel. The SCF oversamples wealthy households, but the responses can be weighted so the results are representative of the entire population. These weights are used to calculate all statistics in our analysis. To account for missing data and other problems with some responses, the SCF panel, like the SCF cross-sectional datasets, imputes some information using five different replicates to approximate the distribution of the missing data. We use the procedure suggested by the Board of Governors staff to correct our standard errors for this feature.

One important feature of our dataset is that the rich background information provided about households allows us to control for other characteristics and features of the economic environment that might be correlated with both leverage and consumption. Most importantly, it allows us to directly control for changes in wealth, as it is highly likely that the housing boom and bust not only influenced leverage but also had a considerable independent effect on consumption choices through the wealth effect. The credit bureau datasets used in the closely related literature on the factors explaining the decline in aggregate household debt offer the advantages of a much larger sample size and less noise (assuming that firms' administrative records are more accurate than households' self-reported information). However, the datasets do not provide a rich set of potential covariates and thus are limited in their capacity to identify the independent effects of leverage.

We measure leverage as a household's debt relative to its assets, as described below. In addition to leverage, we also use several other variables that capture household financial characteristics, including net worth, homeownership status and home value, and liquid assets as a share of 


\section{Dynan and Edelberg}

income. The SCF also provides additional information about critical aspects of household financial experiences between 2007 and 2009. For example, the survey asked whether households refinanced their mortgage between 2007 and 2009. The survey also asked whether households applied for but were denied credit between 2007 and 2009, as well as whether households attribute the reason for such denial to their leverage or similar characteristics.

The SCF also includes information about households' attitudes about credit and the economy, as well as how they manage their money. For example, in 2007 households reported whether they thought buying things on credit was a good idea. In addition, households reported whether they thought the U.S. economy would perform better, worse, or about the same over the next five years as it had over the past five years. Households were also asked about their willingness to take financial risks in return for larger financial returns.

Finally, the survey asked several questions that shed light on households' spending and saving behavior. For example, in both 2007 and 2009, households were asked whether they had saved (i.e., spent less than their total income) over the preceding year. In both years they were also asked whether they "usually" save and how much they need to have in savings for emergencies and other unexpected needs. In addition, in 2009 households reported whether they planned to cut back on spending in various ways and whether they anticipated large future expenditures on a home purchase, health care, and the like.

\section{Measuring Leverage}

It seems there is no apparent consensus in the recent household literature regarding the exact meaning of the terms "leverage" or "deleveraging." Dynan (2012) defines "leverage" as the ratio of a household's debt relative to assets $(\mathrm{D} / \mathrm{A})$, which is closely related to the traditional leverage ratio of assets to net worth used in the corporate finance literature. However, other studies, such as that by Bhutta (2012), associate the term "deleveraging" with declines in the absolute level of debt, and yet others focus on the ratio of household debt to income or even the ratio of household debt service obligations to income (see, for example, Roxburgh et al., 2012).

Our primary measure of leverage is a household's D/A ratio, but we also generally find the results are robust to using the ratio of debt to income (for sake of brevity, the latter results are not shown). One might be concerned about cross-sectional variation being driven by differences in the denominator, such that any differences found for highly leveraged households are actually picking up effects related to the forces that led households to have low assets. Therefore, it is important to include controls that are correlated with these forces. Because leverage is so highly skewed and no doubt measured with error, most of our analysis uses quartiles or centiles of leverage (calculated on a weighted basis).

The timing of our leverage measures also merits further explanation. We primarily group households by their leverage as of 2007-the first year of the panel. We focus on ex ante levels of debt because of concerns that ex post levels of debt (that is, a household's debt as of 2009) may be endogenous with respect to some of the outcome variables of interest in our study. For example, as a group, indebted households that cut back on consumption between 2007 and 2009 for any reason other than high debt should have tended to reduce their debt over the period solely because they needed less debt to finance their lower levels of spending. However, the ex ante 
Dynan and Edelberg

\section{Table 1}

\section{Summary Statistics: 2007-09 SCF Panel}

\begin{tabular}{|c|c|c|c|c|c|}
\hline \multirow[b]{2}{*}{ Statistic } & \multirow[b]{2}{*}{ All households } & \multicolumn{4}{|c|}{ Quartile of 2007 D/A ratio } \\
\hline & & 1 & 2 & 3 & 4 \\
\hline $\mathrm{D} / \mathrm{A}$ ratio $(2007)^{*}$ & 0.22 & 0.00 & 0.10 & 0.37 & 0.84 \\
\hline \multicolumn{6}{|l|}{ Characteristics } \\
\hline Age (yr; in 2007) & 49.42 & 59.03 & 52.42 & 46.54 & 39.69 \\
\hline College degree (2007) & 0.36 & 0.28 & 0.45 & 0.41 & 0.33 \\
\hline Income (in $\$ 1,000$ s, 2007)* & 50.05 & 29.29 & 63.90 & 68.16 & 46.86 \\
\hline Income (in $\$ 1,000$ s, 2009)* & 49.81 & 27.89 & 59.27 & 69.73 & 47.82 \\
\hline Unemployed past year (2007) & 0.15 & 0.13 & 0.11 & 0.13 & 0.23 \\
\hline Unemployed past year (2009) & 0.21 & 0.15 & 0.20 & 0.20 & 0.30 \\
\hline Net worth (in $\$ 1,000$ s, 2007)* & 125.51 & 149.33 & 364.01 & 192.01 & 12.32 \\
\hline Net worth (in $\$ 1,000 s, 2009)^{*}$ & 95.96 & 110.20 & 291.25 & 136.10 & 6.50 \\
\hline Homeowner (2007) & 0.69 & 0.57 & 0.78 & 0.83 & 0.58 \\
\hline Homeowner (2009) & 0.70 & 0.59 & 0.80 & 0.84 & 0.58 \\
\hline \multicolumn{6}{|l|}{ Attitudes } \\
\hline Income uncertain (2007) & 0.27 & 0.28 & 0.23 & 0.25 & 0.31 \\
\hline Income uncertain (2009) & 0.28 & 0.29 & 0.25 & 0.25 & 0.32 \\
\hline OK to use credit (2007) & 0.28 & 0.22 & 0.28 & 0.31 & 0.30 \\
\hline OK to use credit (2009) & 0.27 & 0.24 & 0.24 & 0.30 & 0.30 \\
\hline
\end{tabular}

NOTE: All statistics are means except those marked with an asterisk, which are medians. Quartiles and all statistics were calculated on a weighted basis.

measure of leverage misses the dramatic changes in asset values for many households between 2007 and 2009, owing to the financial crisis and recession. In the SCF survey, the median leverage ratio rose from 0.22 in 2007 (quite high by historical standards) to 0.26 in 2009. As a result, an analysis based solely on ex ante levels could miss some of the effects of leverage shocks that many households experienced. .6

Table 1 shows various characteristics for all households in the 2007-09 SCF and households in different quartiles of leverage. Most households in the first quartile, denoted (1) in the table, had no debt as of 2007 (the upper cutoff value of leverage was about 0.01). The median household in the second-lowest quartile had a $2007 \mathrm{D} / \mathrm{A}$ ratio of 0.10 . The median ratios were 0.37 and 0.84 in the third and fourth (top) quartiles, respectively.

As Table 1 shows, the more-indebted households in 2007 tended to be younger. Those without college degrees were likely to have the highest and lowest levels of leverage. Median income in 2007 rose with debt through the third quartile of leverage but fell back for the top quartile. Not surprisingly, all groups were more likely to have reported an unemployment spell in 2009 than in 2007. In addition, the share with a recent unemployment spell in 2009 rose with leverage.

Net worth in 2007 was higher for households in the second and third quartiles of the D/A ratio distribution compared with those in the first quartile, while, as with income, those in the 


\section{Dynan and Edelberg}

fourth quartile were considerably less affluent than those in the next-lowest quartile. About 80 percent of the households in the second and third quartiles of the D/A ratio distribution were homeowners in 2007, compared with about 60 percent of those in the top and bottom quartiles. Households in the top quartile of the 2007 D/A ratio distribution also appear to have suffered the most on a percentage basis from the financial and housing crises: Their median net worth fell by almost 50 percent over this period compared with declines of between 20 and 30 percent for the other groups. This pattern is consistent with findings in Dynan (2012), Mian, Rao, and Sufi (2013), and many other studies showing that debt was concentrated in the regions with the largest booms and busts in home values. The pattern also underscores the importance of controlling for net worth changes in any study attempting to isolate the effects of debt on household behavior.

The lower panel of Table 1 shows summary statistics for selected variables associated with the attitudes of SCF respondents. As of 2007, households in the top quartile of the D/A ratio distribution were more likely to report uncertainty about the direction of their income over the coming year (although the lowest quartile showed considerable uncertainty). Perhaps not surprisingly, households in the top half of the leverage distribution were more likely to report buying things on credit was a good idea. But, perhaps surprisingly, there was little change in household attitudes about credit between 2007 and 2009.

\section{EVIDENCE ON THE RELATIONSHIP BETWEEN LEVERAGE AND CONSUMPTION}

We use a set of questions about households' financial plans to assess whether leverage had any relationship with spending before we try to discern the underpinnings of the relationship. Overall, we find that leverage is correlated with households' reported spending behavior, even after accounting for the effect of the decline in asset values and other factors that would be expected to independently drive consumption. In later sections, we explore the possible reasons for that role.

\section{Debt and Cutting Back}

In 2009, the SCF asked households what types of decisions they had made "to change the ways you arrange your money or investments" in response to the events of the preceding two years. While the SCF did not ask directly about households' consumption, we use answers to the question on financial planning to make inferences about how households had changed or intended to change their spending behavior. Six of the more than 60 coded responses offered by households appear to be consistent with cutting back consumption in some way:

- "Spend less, cut back."

- "Budget expenses more carefully, more cautious about buying/spending."

- "Use old things longer."

- "Buy less expensive things."

- "No money to spend beyond necessities."

- "Save more." 


\section{Table 2}

\section{Leverage and Share of Households that Reported Cutting Back: 2007-09 SCF Panel}

\begin{tabular}{|c|c|c|c|c|c|}
\hline \multirow{2}{*}{$\begin{array}{l}\text { Sample/subsample } \\
\text { (No. of households) }\end{array}$} & \multirow[b]{2}{*}{ All households } & \multicolumn{4}{|c|}{ Quartile of 2007 D/A ratio } \\
\hline & & 1 & 2 & 3 & 4 \\
\hline Full sample $(3,857)$ & 0.29 & 0.20 & 0.25 & 0.31 & 0.41 \\
\hline $\begin{array}{l}\text { Subsample of homeowners } \\
\text { reporting rise in home value (566) }\end{array}$ & 0.23 & 0.13 & 0.19 & 0.23 & 0.39 \\
\hline $\begin{array}{l}\text { Subsample of homeowners } \\
\text { reporting rise in home value, net worth, } \\
\text { and income (154) }\end{array}$ & 0.21 & 0.12 & 0.15 & 0.17 & 0.39 \\
\hline
\end{tabular}

The SCF allows each household to report up to 10 different changes. For our analysis, we created a variable equal to 1 if a household reported making one or more of the above changes and 0 otherwise.

The first row of Table 2 shows the shares of households that reported cutting back in 2009 for the entire sample as a group and according to leverage quartiles. As the first column ("All households") shows, close to 30 percent of households reported trimming their spending plans in some way. For households with different levels of debt relative to assets in 2007, the propensity to report cutting back in 2009 rises with leverage. In the top quartile, 41 percent of households reported cutting back in some way compared with 20 percent of households in the lowest quartile.

As noted, it is important for our analysis to control in some way for features of households' economic environments that might be correlated with leverage. The plunge in households' asset values should have had its own effect on consumer spending through the usual wealth effect channel. We also attempted to control for the correlation between other adverse economic developments (e.g., loss of income) and household leverage. The remainder of the table does this simply by limiting the sample. We start with restrictions based on changes in homeownerreported home values because the most obvious bias would arise from the relationship between debt and home value declines produced by the housing bubble. As the middle row of the table shows, the pattern for the much smaller subsample of homeowners who reported a rise in their home value over the 2007-09 period is even starker than that for the full sample, with an even more-pronounced difference between homeowners holding the most and the least debt relative to their assets. The pattern holds up even when we restrict the sample to the very small and very fortunate group of homeowners that reported that their home values, their net worth, and their incomes all increased between 2007 and 2009 (last row). Strikingly, a comparison of the first and third rows of the final column indicates the most-indebted households in this group showed nearly as high a propensity to cut back as the most-indebted households in the population at large. This latter result is consistent with the view that the greater propensity of more-indebted households to report cutting back is indeed largely debt-related and does not simply reflect the 


\section{Dynan and Edelberg}

other dramatic changes these households may have personally experienced in the wake of the housing bust and the Great Recession.

In Table 3, we formalize the result using a probit regression, which allows us to explore the relationship between cutting back and leverage for a broad group of households while controlling for net worth, income, and other factors. The dependent variable for the regression was whether a household reporting cutting back. The key coefficients of interest are those on the variables capturing households' D/A ratio, shown at the bottom of the table. We include a wide range of controls in an effort to remove the effects of other household features possibly correlated with leverage and driving decisions to cut back. These controls include two categorical variables capturing the deciles into which the 2007-09 changes in households' income and net worth fell, respectively. $\underline{7}$ We also included age, indicator variables for experiences such as spells of unemployment, measures capturing the emergency funds available to households (their liquid assets and access to funds from friends and relatives), as well as a number of variables that captured their expectations and attitudes.

Our baseline sample consists of households owning homes in both 2007 and 2009 that did not move. We focus on this group because moving might be associated with other developments, leading to both a change in spending behavior and a change in debt that might bias our results, although the estimated coefficients on the debt-related variables are generally similar when the

full sample is used. The first three columns in Table 3 differ in the debt-related variables included. Column (1) contains a variable corresponding to the 2007 D/A quartile, column (2) contains separate indicator variables for each of the quartiles, and column (3) contains an indicator variable capturing the $2007 \mathrm{D} / \mathrm{A}$ decile, along with the squared value of this variable to detect nonlinear effects. The results across the three columns tell a similar story: The estimated coefficients suggest a positive and statistically significant relationship between a household's leverage and its propensity to cut back. Columns (4) and (5) are similar to column (1) in specification but show the results when the sample is (i) restricted to homeowners with increased home values and then (ii) further restricted to those who also experienced increased net worth and income. Not surprisingly, the standard errors are considerably higher for these smaller subsamples. However, the estimated coefficients on leverage are still positive (and statistically significant in column (4)). All in all, the positive relationship between leverage and a desire to cut back holds up in this more formal context.

Many of the estimated coefficients on the control variables in these regressions are as expected. Among the more notable results, greater income and net worth changes are associated with a reduced likelihood of cutting back (surprisingly, though, these coefficients are not statistically significant, nor were those on any of the variations we tried in specifications not shown). Experiencing an unemployment spell and expecting significant future expenses were associated with a greater propensity to report cutting back, and being willing to take risks as of 2007 was associated with a reduced propensity to report cutting back in 2009. 


\section{Table 3}

\section{Probit Regression Results (Dependent Variable = Whether Cutting Back)}

\begin{tabular}{|c|c|c|c|c|c|}
\hline & (1) & (2) & (3) & (4) & (5) \\
\hline Characteristic & All households & All households & All households & $\begin{array}{c}\text { Households } \\
\text { with increases in } \\
\text { home values }\end{array}$ & $\begin{array}{l}\text { Households with } \\
\text { increases in home } \\
\text { values, incomes, } \\
\text { and net worth }\end{array}$ \\
\hline Age class & $\begin{array}{c}-0.120^{* *} \\
(0.025)\end{array}$ & $\begin{array}{c}-0.120 \\
(0.120)\end{array}$ & $\begin{array}{c}-0.110 \\
(0.110)\end{array}$ & $\begin{array}{c}-0.148^{* *} \\
(0.060)\end{array}$ & $\begin{array}{c}-0.241^{*} \\
(0.136)\end{array}$ \\
\hline Had unemployment spell & $\begin{array}{l}0.359^{* *} \\
(0.081)\end{array}$ & $\begin{array}{c}0.361 \\
(0.361)\end{array}$ & $\begin{array}{l}0.355 \\
0.355\end{array}$ & $\begin{array}{l}0.436 * * \\
(0.176)\end{array}$ & $\begin{array}{l}1.0352^{* *} \\
(0.386)\end{array}$ \\
\hline Has access to funds & $\begin{array}{c}-0.029 \\
(0.067)\end{array}$ & $\begin{array}{c}-0.034 \\
(0.157)\end{array}$ & $\begin{array}{c}-0.031 \\
(0.157)\end{array}$ & $\begin{array}{c}0.030 \\
(0.161)\end{array}$ & $\begin{array}{c}0.584 \\
(0.411)\end{array}$ \\
\hline Okay to use credit & $\begin{array}{c}0.053 \\
(0.067)\end{array}$ & $\begin{array}{c}0.052 \\
(0.039)\end{array}$ & $\begin{array}{c}0.049 \\
(0.123)\end{array}$ & $\begin{array}{c}0.055 \\
(0.156)\end{array}$ & $\begin{array}{c}0.280 \\
(0.407)\end{array}$ \\
\hline Expect improved economy & $\begin{array}{c}0.123^{*} \\
(0.063)\end{array}$ & $\begin{array}{c}0.123 \\
(0.124)\end{array}$ & $\begin{array}{l}0.122^{* *} \\
(0.014)\end{array}$ & $\begin{array}{c}-0.092 \\
(0.162)\end{array}$ & $\begin{array}{c}-0.277 \\
(0.412)\end{array}$ \\
\hline Expect large future expenses & $\begin{array}{l}0.146^{* *} \\
(0.058)\end{array}$ & $\begin{array}{l}0.143^{* *} \\
(0.013)\end{array}$ & $\begin{array}{c}0.147 \\
(0.139)\end{array}$ & $\begin{array}{c}0.202 \\
(0.140)\end{array}$ & $\begin{array}{c}0.038 \\
(0.368)\end{array}$ \\
\hline Change in income class & $\begin{array}{c}-0.008 \\
(0.011)\end{array}$ & $\begin{array}{c}-0.008 \\
(0.695)\end{array}$ & $\begin{array}{c}-0.009 \\
(0.007)\end{array}$ & & \\
\hline Income uncertain & $\begin{array}{c}-0.013 \\
(0.065)\end{array}$ & $\begin{array}{c}-0.011 \\
(0.418)\end{array}$ & $\begin{array}{c}-0.003 \\
(0.011)\end{array}$ & $\begin{array}{c}-0.121 \\
(0.162)\end{array}$ & $\begin{array}{c}0.065 \\
(0.427)\end{array}$ \\
\hline Liquid assets/income & $\begin{array}{c}-0.001 \\
(0.027)\end{array}$ & $\begin{array}{c}0.001 \\
(0.054)\end{array}$ & $\begin{array}{c}0.004 \\
(0.051)\end{array}$ & $\begin{array}{c}-0.049 \\
(0.100)\end{array}$ & $\begin{array}{c}-1.100 \\
(0.878)\end{array}$ \\
\hline Change in net worth class & $\begin{array}{c}-0.014 \\
(0.010)\end{array}$ & $\begin{array}{c}-0.014 \\
(0.144)\end{array}$ & $\begin{array}{c}-0.013 \\
(0.148)\end{array}$ & & \\
\hline Willing to take risks in 2007 & $\begin{array}{c}-0.152^{* * *} \\
(0.063)\end{array}$ & $\begin{array}{c}-0.157^{* *} \\
(0.016)\end{array}$ & $\begin{array}{c}-0.156^{* *} \\
(0.016)\end{array}$ & $\begin{array}{c}-0.262 \\
(0.160)\end{array}$ & $\begin{array}{c}-0.258 \\
(0.411)\end{array}$ \\
\hline 2007 D/A quartile & $\begin{array}{l}0.219^{* *} \\
(0.036)\end{array}$ & & & $\begin{array}{l}0.156^{* * *} \\
(0.079)\end{array}$ & $\begin{array}{c}0.062 \\
(0.221)\end{array}$ \\
\hline 2007 D/A quartile 1 & & $\begin{array}{c}-0.695^{* *} \\
(0.196)\end{array}$ & & & \\
\hline 2007 D/A quartile 2 & & $\begin{array}{c}-0.418^{* *} \\
(0.055)\end{array}$ & & & \\
\hline 2007 D/A quartile 3 & & $\begin{array}{c}-0.191^{* *} \\
(0.028)\end{array}$ & & & \\
\hline 2007 D/A quartile 4 & & $\begin{array}{c}-0.046 \\
(0.030)\end{array}$ & & & \\
\hline 2007 D/A decile class & & & $\begin{array}{c}0.138^{* *} \\
(0.014)\end{array}$ & & \\
\hline 2007 D/A decile 2 & & & $\begin{array}{c}-0.004 \\
(0.956)\end{array}$ & & \\
\hline
\end{tabular}

NOTE: Sample restricted to homeowners who did not move. Standard errors are indicated in parentheses. * indicates significance at the 10 percent or higher level; ${ }^{* *}$ indicates significance at the 5 percent or higher level. 


\section{Dynan and Edelberg}

\section{Table 4}

Household Access to Credit Between 2007 and 2009: 2007-09 SCF Panel

\begin{tabular}{|c|c|c|c|c|c|}
\hline \multirow[b]{2}{*}{ Characteristic } & \multirow[b]{2}{*}{ All households } & \multicolumn{4}{|c|}{ Quartile of 2007 D/A ratio } \\
\hline & & 1 & 2 & 3 & 4 \\
\hline Share applying for credit & 0.47 & 0.21 & 0.51 & 0.56 & 0.58 \\
\hline $\begin{array}{l}\text { Share reporting having been } \\
\text { denied credit at some point }\end{array}$ & 0.12 & 0.04 & 0.08 & 0.14 & 0.21 \\
\hline Ratio & 0.25 & 0.19 & 0.16 & 0.25 & 0.36 \\
\hline $\begin{array}{l}\text { Share reporting having not applied } \\
\text { for credit at some point because they } \\
\text { feared being denied }\end{array}$ & 0.17 & 0.12 & 0.11 & 0.18 & 0.28 \\
\hline
\end{tabular}

\section{EVIDENCE ON WHY HIGH LEVERAGE MAY BE CONSTRAINING CONSUMPTION}

In this section, we use the 2007-09 SCF to explore possible explanations for the observed positive relationship between a household's leverage and its propensity to report cutting back spending. We look at responses to the following question from the 2009 resurvey: "In the past two years, has a particular lender or creditor turned down any request you made for credit, or not given you as much credit as you applied for?" We label a household as being denied if it reported being turned down for credit. $\underline{8}$

Table 4 shows how being turned down for credit varies across households with different degrees of leverage. The first row shows that more-leveraged households were more likely to have applied for credit between 2007 and 2009 than their counterparts with less leverage. They were also more likely to have been denied; 21 percent of households in the top quartile of the 2007 D/A ratio were turned down for credit at least once compared with 12 percent for the sample as a whole. These figures imply that the share of households that applied for credit between 2007 and 2009 and was denied credit at some point was somewhat higher for highly leverage households (36 percent in the top quartile) than for all households in the SCF panel (25 percent). The fourth row shows further evidence of debt-related constraints; it shows the shares of households reporting they considered applying for credit at some point between 2007 and 2009 but did not do so because they feared being turned down. The share of households in the top quartile of $2007 \mathrm{D} / \mathrm{A}$ in this category was 28 percent, compared with 17 percent for the sample as a whole.

The clearest "take-away" message from this analysis is that the higher leverage of some households appeared to impair their access to credit over the 2007-09 period and, in turn, likely limited their consumption. This conclusion is perhaps not surprising given that lenders make underwriting decisions based in part on household leverage. 


\section{Leverage, Credit Access, and Cutting Back}

We examine whether the relationship between leverage and access to credit fully explains the relationship between leverage and a household's desire to cut back. Since more highly leveraged households appear to have less access to credit, and less access to credit should lower consumer spending, our results in the previous section may reflect that indirect effect of leverage on spending. To gauge the importance of this channel, we augment the probit specification used for Table 3 to include a measure of whether households were denied credit. If the measure fully captures whether households lack access to credit and if leverage has no effect on households' financial decisions other than through its effect on access to credit, we would expect leverage to no longer predict households' reported plans to cut back on spending after that measure is included. 9

Table 5 shows the estimation results for our baseline sample. The columns are identical to the first three specifications estimated for Table 3, but we added the indicator variable for whether a household was turned down for credit between 2007 and 2009 to the set of independent variables. As shown, the coefficients on the leverage variables remain statistically significant and are, in fact, similar in magnitude to their counterparts in Table 3. Thus, even after including whether a household has been denied credit, the estimated coefficients suggest a positive and statistically significant relationship between a household's leverage and its propensity to cut back its expenses. All in all, the results suggest that leverage is an important factor in a household's financial decisions beyond its effect on access to credit.

\section{Leverage and Refinancing}

As discussed earlier, difficulty in refinancing a mortgage may also contribute to the correlation between leverage and a household's propensity to cut back. Between mid-2007 and mid2009 , the interest rate on new 30-year fixed-rate mortgages fell by about 11/4 percentage points; a reduction of this magnitude in the interest rate on a mortgage of $\$ 100,000$ would lower monthly payments by about $\$ 80$, creating an annual increase in cash flow of about $\$ 950$. For many households with low financial assets (see, for example, Bricker et al., 2012) and a limited ability to borrow through credit cards over the 2007-09 period, such an increase in cash flow could have a significant impact on consumption. However, many homeowners were not able to realize that increase in cash flow: Highly leveraged households (especially those under water on their mortgages) had difficulty refinancing their mortgages, particularly relative to households with less leverage. $\underline{10}$

Table 6 provides some evidence from the 2007-09 SCF panel on the relationship between leverage and refinancing. As the first column shows, 14 percent of all households (first row), or 20 percent of households with mortgages (third row), reported refinancing their mortgages between 2007 and 2009. 11 As the third row shows, very high leverage does appear to affect a household's ability to refinance. The share of mortgage holders that refinanced is 6 percentage points lower in the top quartile than in the next-highest quartile and 3 percentage points lower than for the sample as a whole. As the final row of the table shows, the median reduction in 


\section{Dynan and Edelberg}

Table 5

Probit Regression Results (Dependent Variable $=$ Whether Cutting Back, including measures of credit constraints)

\begin{tabular}{|c|c|c|c|}
\hline Characteristic & (1) & (2) & (3) \\
\hline Age class & $\begin{array}{c}-0.111^{* *} \\
(0.027)\end{array}$ & $\begin{array}{l}-0.110^{* *} \\
(0.027)\end{array}$ & $\begin{array}{c}-0.098^{* *} \\
(0.028)\end{array}$ \\
\hline Had unemployment spell & $\begin{array}{l}0.393^{* *} \\
(0.089)\end{array}$ & $\begin{array}{l}0.392^{* * *} \\
(0.089)\end{array}$ & $\begin{array}{l}0.384^{* *} \\
(0.089)\end{array}$ \\
\hline Has access to funds & $\begin{array}{c}-0.017 \\
(0.074)\end{array}$ & $\begin{array}{c}-0.022 \\
(0.074)\end{array}$ & $\begin{array}{c}-0.014 \\
(0.075)\end{array}$ \\
\hline Okay to use credit & $\begin{array}{c}0.068 \\
(0.071)\end{array}$ & $\begin{array}{c}0.066 \\
(0.071)\end{array}$ & $\begin{array}{c}0.062 \\
(0.071)\end{array}$ \\
\hline Expect improved economy & $\begin{array}{c}0.122^{*} \\
(0.067)\end{array}$ & $\begin{array}{c}0.122^{*} \\
(0.068)\end{array}$ & $\begin{array}{c}0.120^{*} \\
(0.067)\end{array}$ \\
\hline Expect large future expenses & $\begin{array}{c}0.125^{* *} \\
(0.062)\end{array}$ & $\begin{array}{c}0.119^{*} \\
(0.062)\end{array}$ & $\begin{array}{l}0.125^{* *} \\
(0.062)\end{array}$ \\
\hline Change in income class & $\begin{array}{c}-0.004 \\
(0.011)\end{array}$ & $\begin{array}{c}-0.004 \\
(0.011)\end{array}$ & $\begin{array}{c}-0.006 \\
(0.011)\end{array}$ \\
\hline Income uncertain & $\begin{array}{c}-0.001 \\
(0.070)\end{array}$ & $\begin{array}{c}0.000 \\
(0.070)\end{array}$ & $\begin{array}{c}0.011 \\
(0.070)\end{array}$ \\
\hline Percent of credit limit used & $\begin{array}{c}0.000 \\
(0.000)\end{array}$ & $\begin{array}{c}0.000 \\
(0.000)\end{array}$ & $\begin{array}{c}0.000 \\
(0.000)\end{array}$ \\
\hline Liquid assets/income & $\begin{array}{c}-0.005 \\
(0.029)\end{array}$ & $\begin{array}{c}-0.003 \\
(0.029)\end{array}$ & $\begin{array}{c}0.003 \\
(0.028)\end{array}$ \\
\hline Change in net worth class & $\begin{array}{c}-0.015 \\
(0.010)\end{array}$ & $\begin{array}{c}-0.014 \\
(0.010)\end{array}$ & $\begin{array}{c}-0.014 \\
(0.010)\end{array}$ \\
\hline Willing to take risks in 2007 & $\begin{array}{c}-0.131^{* *} \\
(0.066)\end{array}$ & $\begin{array}{l}-0.138^{* *} \\
(0.066)\end{array}$ & $\begin{array}{c}-0.137^{* *} \\
(0.066)\end{array}$ \\
\hline Denied credit & $\begin{array}{l}0.289 * * \\
(0.096)\end{array}$ & $\begin{array}{l}0.303^{* *} \\
0.096)\end{array}$ & $\begin{array}{c}0.301^{* *} \\
(0.095)\end{array}$ \\
\hline 2007 D/A quartile & $\begin{array}{c}0.213^{* *} \\
(0.041)\end{array}$ & & \\
\hline 2007 D/A quartile 1 & & $\begin{array}{c}-0.821^{* *} \\
(0.182)\end{array}$ & \\
\hline 2007 D/A quartile 2 & & $\begin{array}{c}-0.497^{* *} \\
(0.160)\end{array}$ & \\
\hline 2007 D/A quartile 3 & & $\begin{array}{c}-0.319^{* *} \\
(0.157)\end{array}$ & \\
\hline 2007 D/A quartile 4 & & $\begin{array}{c}-0.173 \\
(0.163)\end{array}$ & \\
\hline 2007 D/A decile class & & & $\begin{array}{c}0.186^{* *} \\
(0.052)\end{array}$ \\
\hline 2007 D/A decile 2 & & & $\begin{array}{c}-0.009^{*} \\
(0.005)\end{array}$ \\
\hline
\end{tabular}




\section{Table 6}

\section{Mortgage Refinancings between 2007 and 2009: 2007-09 SCF Panel}

\begin{tabular}{lccccc} 
& & \multicolumn{4}{c}{ Quartile of 2007 D/A ratio } \\
\cline { 3 - 6 } Characteristic & All households & $\mathbf{1}$ & $\mathbf{2}$ & $\mathbf{3}$ & $\mathbf{4}$ \\
\hline Share refinancing & 0.14 & 0.01 & 0.14 & 0.22 & 0.17 \\
Share with mortgage & 0.69 & 0.02 & 0.70 & 0.95 & 0.97 \\
Share with mortgage that refinanced & 0.20 & 0.05 & 0.18 & -23 & -43 \\
Median change in payment & -36 & $\ldots$ & -47
\end{tabular}

for refinancers $(\$ /$ month)

NOTE: Quartiles and all statistics were calculated on a weighted basis. Shares are based on the full sample of 3,857 households. The reference period for all shares was the two years preceding the 2009 resurvey. The ellipsis signifies that the relevant sample was too small to produce reliable figures.

mortgage payments for households that were able to refinance was meaningful, amounting to $\$ 47$ a month in higher cash flow (\$564 a year) for those in the top quartile of debt relative to assets and $\$ 36$ a month (\$432 a year) for all households that refinanced.

The results in Table 6 indicate that higher leverage likely dampened a household's ability to refinance, which in turn dampened cash flow and spending. However, more work is warranted in this area, particularly given that such a linkage has implications about whether policy initiatives aimed at facilitating refinancing for highly leveraged households are an effective way to raise aggregate demand. Most importantly, the simple framework used here likely does not cleanly separate credit supply effects from demand effects as there is a higher payoff to refinancing for households with more mortgage debt.

\section{Leverage, Refinancing, and Cutting Back}

We look for evidence regarding whether an impaired ability to refinance might explain the higher propensity of more highly leveraged households to indicate cutting back consumption by reestimating the specifications from Table 5 including an indicator variable for whether a household had refinanced between 2007 and 2009. The results are shown in Table 7.

Leverage still appears to play a direct role in predicting whether a household reports cutting back on spending after adding whether the household refinanced. The estimated coefficient on the refinancing variable is of the expected sign (negative, implying that households that refinanced were less likely to report cutting back on spending). However, it is statistically insignificant, which might suggest that the change in cash flow induced by refinancing was not very relevant to a household's spending over this period. (It may also reflect the presumably high degree of collinearity between a household's access to credit and its ability to refinance.) More importantly, the estimated coefficients on the leverage terms remain statistically significant, consistent with the view that leverage might affect spending in ways that extend beyond its indirect effects on access to credit and cash flow increased by refinancing. 


\section{Dynan and Edelberg}

Table 7

Probit Regression Results (Dependent Variable $=$ Whether Cutting Back, including indicator of refinancing)

\begin{tabular}{|c|c|c|c|}
\hline Characteristic & (1) & (2) & (3) \\
\hline Age class & $\begin{array}{c}-0.089^{* * *} \\
(0.033)\end{array}$ & $\begin{array}{c}-0.090 \\
(0.090)\end{array}$ & $\begin{array}{c}-0.074 \\
(0.074)\end{array}$ \\
\hline Had unemployment spell & $\begin{array}{l}0.345^{* *} \\
(0.098)\end{array}$ & $\begin{array}{c}0.347 \\
(0.348)\end{array}$ & $\begin{array}{c}0.338 \\
(0.338)\end{array}$ \\
\hline Has access to funds & $\begin{array}{r}-0.016 \\
(0.087)\end{array}$ & $\begin{array}{r}-0.015 \\
(0.202)\end{array}$ & $\begin{array}{c}-0.007 \\
(0.184)\end{array}$ \\
\hline Okay to use credit & $\begin{array}{c}0.087 \\
(0.079)\end{array}$ & $\begin{array}{l}0.086^{* * *} \\
(0.022)\end{array}$ & $\begin{array}{l}0.090^{* *} \\
(0.040)\end{array}$ \\
\hline Expect improved economy & $\begin{array}{c}0.046 \\
(0.079)\end{array}$ & $\begin{array}{c}0.045^{* *} \\
(0.012)\end{array}$ & $\begin{array}{c}0.038 \\
(0.321)\end{array}$ \\
\hline Expect large future expenses & $\begin{array}{c}0.095 \\
(0.073)\end{array}$ & $\begin{array}{c}0.098 \\
(0.327)\end{array}$ & $\begin{array}{l}0.107^{* *} \\
(0.030)\end{array}$ \\
\hline Change in income class & $\begin{array}{c}-0.004 \\
(0.014)\end{array}$ & $\begin{array}{c}-0.004 \\
(0.021)\end{array}$ & $\begin{array}{c}-0.006 \\
(0.254)\end{array}$ \\
\hline Income uncertain & $\begin{array}{c}-0.014 \\
(0.084)\end{array}$ & $\begin{array}{r}-0.016 \\
(0.467)\end{array}$ & $\begin{array}{c}0.005 \\
(0.016)\end{array}$ \\
\hline Percent of credit limit used & $\begin{array}{c}0.000 \\
(0.000)\end{array}$ & $\begin{array}{c}0.000 \\
(0.024)\end{array}$ & $\begin{array}{c}0.000 \\
(0.009)\end{array}$ \\
\hline Liquid assets/income & $\begin{array}{r}-0.024 \\
(0.044)\end{array}$ & $\begin{array}{c}-0.023 \\
(0.020)\end{array}$ & $\begin{array}{c}-0.015 \\
(1.348)\end{array}$ \\
\hline Change in net worth class & $\begin{array}{c}-0.025^{* *} \\
(0.012)\end{array}$ & $\begin{array}{c}-0.025 \\
(0.086)\end{array}$ & $\begin{array}{c}-0.028 \\
(0.090)\end{array}$ \\
\hline Willing to take risks in 2007 & $\begin{array}{c}-0.196 * * \\
(0.077)\end{array}$ & $\begin{array}{c}-0.200^{* *} \\
(0.030)\end{array}$ & $\begin{array}{c}-0.183^{* *} \\
(0.032)\end{array}$ \\
\hline Denied credit & $\begin{array}{l}0.327^{* *} \\
(0.103)\end{array}$ & $\begin{array}{l}0.327^{* *} \\
(0.048)\end{array}$ & $\begin{array}{l}0.321^{* *} \\
(0.014)\end{array}$ \\
\hline Refinanced & $\begin{array}{c}-0.017 \\
(0.083)\end{array}$ & $\begin{array}{c}-0.019 \\
(0.099)\end{array}$ & $\begin{array}{c}-0.027 \\
(0.108)\end{array}$ \\
\hline 2007 D/A quartile & $\begin{array}{l}0.172^{* *} \\
(0.054)\end{array}$ & & \\
\hline 2007 D/A quartile 1 & & $\begin{array}{c}-0.461 \\
(0.466)\end{array}$ & \\
\hline 2007 D/A quartile 2 & & $\begin{array}{c}-0.456^{*} \\
(0.244)\end{array}$ & \\
\hline 2007 D/A quartile 3 & & $\begin{array}{c}-0.236^{*} \\
(0.124)\end{array}$ & \\
\hline 2007 D/A quartile 4 & & $\begin{array}{c}-0.099 * \\
(0.056)\end{array}$ & \\
\hline 2007 D/A decile & & & $\begin{array}{l}0.254^{* *} \\
(0.017)\end{array}$ \\
\hline 2007 D/A decile 2 & & & $\begin{array}{c}-0.013 \\
(0.017)\end{array}$ \\
\hline
\end{tabular}




\section{Leverage and Precautionary Behavior}

The previous discussion suggests that precautionary concerns might induce highly leveraged households to be more likely to reduce spending. In particular, highly leveraged households might worry about future access to credit. They might anticipate a higher cost of job loss because they believe (correctly) that their high levels of leverage might make it more difficult to borrow to sustain their spending. Moreover, such concerns would likely have increased after the onset of the financial crisis and recession as both the risk of job loss and concerns about future access to credit worsened. In a related manner, highly leveraged households might tend to report greater precautionary concerns if they are uncomfortable because their leverage is too high compared with a behavioral benchmark.

Unfortunately, the SCF does not provide explicit information about households' expectations regarding their future access to credit or their desired leverage ratios, so it is difficult to directly test these channels. However, we can look for evidence of greater precautionary concerns in general, which might be expected to be correlated with worries about future credit access and higher-than-desired leverage.

To begin, households with greater precautionary concerns in 2009 presumably would be less willing to assume financial risk than before the financial crisis and recession. Thus, in Table 8, we examine the relationship between leverage and the change over time in responses to the following question:

Which of the following statements comes closest to describing the amount of financial risk that you are willing to take when you save or make investments?

1. Take substantial financial risks expecting to earn substantial return

2. Take above average financial risks expecting to earn above average returns

3. Take average financial risks expecting to earn average returns

4. Not willing to take any financial risks

We identify households as willing to take risks if they select either the first or the second response above.

Table 8 shows that the change in willingness to assume financial risk varied by leverage; a larger share of highly leveraged households showed a reduction in risk tolerance. As the first two rows show, households in the top half of the leverage distribution have a higher average tolerance for risk than those with less leverage. In addition, tolerance for risk declined between 2007 and 2009 for households across all four leverage quartiles. However, the share with a decline was higher for households with more leverage. The third row of the table shows the share of households that reported less tolerance for risk in 2009 than in 2007; in other words, the difference between each household's 2007 and 2009 response was negative. The results in this row also indicate that a larger share of highly leveraged households showed a reduction in risk tolerance relative to their counterparts with less leverage. Interestingly, the last line of the table shows this difference is even more pronounced for the relatively fortunate households that experienced an increase in home values, incomes, and net worth. 


\section{Dynan and Edelberg}

\section{Table 8}

Changes in Households' Tolerance for Financial Risk between 2007 and 2009: 2007-09 SCF Panel

\begin{tabular}{|c|c|c|c|c|c|}
\hline \multirow[b]{2}{*}{ Characteristic } & \multirow[b]{2}{*}{ All households } & \multicolumn{4}{|c|}{ Quartile of 2007 D/A ratio } \\
\hline & & 1 & 2 & 3 & 4 \\
\hline \multicolumn{6}{|l|}{ Share willing to take financial risk: } \\
\hline 2007 & 0.21 & 0.10 & 0.25 & 0.27 & 0.21 \\
\hline 2009 & 0.15 & 0.07 & 0.18 & 0.19 & 0.15 \\
\hline $\begin{array}{l}\text { Share reporting less willingness to take } \\
\text { financial risk in } 2009 \text { than in } 2007\end{array}$ & 0.26 & 0.19 & 0.27 & 0.29 & 0.29 \\
\hline $\begin{array}{l}\text { Share reporting less willingness to take } \\
\text { financial risk in } 2009 \text { than in } 2007 \text { with } \\
\text { increases in home value, income, and } \\
\text { net worth }\end{array}$ & 0.25 & 0.11 & 0.20 & 0.30 & 0.32 \\
\hline
\end{tabular}

The SCF also asks respondents a question that assesses their need for precautionary savings: "About how much do you think you (and your family) need to have in savings for emergencies and other unexpected things that may come up?" Table 9 summarizes the responses to this answer. In both 2007 and 2009, the households with the most leverage reported lower precautionary needs in terms of dollar amounts. However, when these needs are compared with the liquid assets available, the most highly leveraged households tended to fall short of their desired needs; in other words, the median needs as a share of liquid assets were greater than 1. Furthermore, shortfalls for the mostly highly leveraged households were larger than for other groups. Indeed, in 2007, other groups tended to have enough liquid assets for precautionary purposes, with median ratios less than or equal to 1. The dollar amounts and shares for all groups rose between 2007 and 2009, as might be expected given the turmoil in economic conditions. In addition, the share increase was much larger for highly leveraged households than for those with less leverage. In 2009 , households in the top quartile of leverage reported needing an amount of precautionary reserves more than three times as high as the value of their actual liquid assets. Even highly leveraged households fortunate enough to experience increases in their home values, incomes, and overall net worth show a considerably greater shortfall than their counterparts with less leverage. Given these large gaps, it is not surprising that highly leveraged households were more likely to report cutting back on spending. $\cdot \frac{12}{}$

Thus, relative to households with less leverage, highly leveraged households not only showed a greater drop in risk tolerance but also a more pronounced jump in concerns about their ability to sustain their spending in the face of adverse economic developments. This evidence seems consistent with the view that high leverage may dampen spending partly through the indirect channel of heightening households' fears of not having access to credit in the future. However, we cannot be certain of this link given that the SCF questions explored are so loosely related to expectations of future borrowing constraints. Admittedly, the evidence could also be consistent 


\section{Table 9}

\section{Households' Precautionary Needs in 2007 and 2009: 2007-09 SCF Panel}

\begin{tabular}{|c|c|c|c|c|c|}
\hline \multirow[b]{2}{*}{ Characteristic } & \multirow[b]{2}{*}{ All households } & \multicolumn{4}{|c|}{ Quartile of 2007 D/A ratio } \\
\hline & & 1 & 2 & 3 & 4 \\
\hline \multicolumn{6}{|l|}{2007} \\
\hline $\begin{array}{l}\text { Median of desired precautionary } \\
\text { reserves }\end{array}$ & $\$ 5,000$ & $\$ 5,000$ & $\$ 5,000$ & $\$ 5,000$ & $\$ 3,000$ \\
\hline $\begin{array}{l}\text { Median of desired precautionary } \\
\text { reserves as a share of liquid assets* }\end{array}$ & 1.1 & 0.9 & 0.9 & 1.0 & 1.6 \\
\hline \multicolumn{6}{|l|}{2009} \\
\hline $\begin{array}{l}\text { Median of desired precautionary } \\
\text { reserves }\end{array}$ & $\$ 6,000$ & $\$ 5,300$ & $\$ 10,000$ & $\$ 6,800$ & $\$ 5,000$ \\
\hline $\begin{array}{l}\text { Median of desired precautionary } \\
\text { reserves as a share of liquid assets* }\end{array}$ & 1.7 & 1.4 & 1.3 & 1.4 & 3.3 \\
\hline $\begin{array}{l}\text { Median of desired precautionary } \\
\text { reserves as a share of liquid assets with } \\
\text { increases in home value, income, and } \\
\text { net worth* }\end{array}$ & 1.4 & 0.9 & 1.3 & 1.1 & 2.3 \\
\hline
\end{tabular}

with high leverage simply making households feel uncomfortable or vulnerable in some vague way-the "direct" channel described earlier. Given these uncertainties about interpretation of these results, we do not attempt to formalize the analysis by adding these measures to a probit regression as we did for the credit access and refinancing measures.

\section{CONCLUSION}

Results from the 2007-09 Survey of Consumer Finances are consistent with earlier research suggesting that high leverage has contributed to the lackluster growth in consumer spending since the onset of the recent recession. In particular, we find highly leveraged households were more likely to report spending cutbacks even after controlling for other factors expected to influence spending, such as changes in income and wealth. Furthermore, evidence suggests this linkage likely arises from several channels, including not only effects of high leverage on current access to credit and the ability to refinance, but also precautionary worries about the effects of leverage on future access to credit (and, possibly, worries related to their leverage being higher than a target ratio).

Future research should drill down further into the underpinnings of the relationship between leverage and spending. More work is needed to cleanly separate the different channels of causation. As yet, we have tapped only a limited portion of the rich set of attitudinal variables in the dataset to explore why high leverage may induce some households to cut back spending. More 


\section{Dynan and Edelberg}

comprehensive results in this area will shed light on what current levels of leverage (which still remain quite elevated for many households) might predict for the macroeconomic outlook and the efficacy of different policy options in the future.

\section{NOTES}

1 Cooper (2012) emphasizes that a negative relationship between consumption and debt at the household level existed before the Great Recession, suggesting that behavior itself does not appear to have changed in recent years. Thus, any dampening effect of debt on consumption at the aggregate level would have to be the result of more households being burdened by debt and leverage than in recent periods.

$\underline{2}$ See Carroll, Slacalek, and Sommer (2012) for a somewhat different interpretation of how changes in the risk of job loss might cause borrowing constraints to change over time.

3 Allowing a highly leveraged borrower to refinance at a lower rate has partially offsetting effects for the original mortgage lender. On one hand, the lender earns less because of the drop in interest payments. On the other hand, by improving the borrower's cash flow, the decline in interest payments reduces the likelihood of a highly leveraged borrower defaulting. In the years following the financial crisis, lenders were generally unwilling to refinance mortgages for highly leveraged borrowers, suggesting that lenders estimated that those costs outweighed the benefits.

4 Casselman (2012) provides an anecdotal accounting of the concerns expressed by borrowers who perceive they have too much debt.

$\underline{5}$ Mishkin (1977) argued that such behavior contributed to the unusually weak 1973-75 recession.

$\underline{6}$ Note that coefficients on ex ante leverage should pick up some effects of the shock if these levels were correlated with the subsequent shock. Given that the highest levels of debt were seen in the areas with the largest housing busts (and, relatedly, the largest economic slumps), one might expect this to be the case. Indeed, we did find that the estimated coefficients were little changed when we substituted 2009 leverage for 2007 leverage in the regression analysis of households' propensities to say they were "cutting back."

7 We classified households based on the 2007-09 change in net worth relative to 2007 income and the 2007-09 percent change in income. We used the decile groupings rather than the actual changes to avoid undue weighting of extreme observations. However, we used the actual changes (as well other variants on these variables) and found little difference for the estimated coefficients of interest.

$\underline{8}$ A somewhat similar question was asked in the 2007 wave, but we found it did not provide a useful benchmark for credit access because the look-back period was much longer-the preceding five years. The longer look-back period may explain why the frequency of households reporting they were denied credit was actually higher in this earlier wave despite the subsequent dramatic tightening of credit conditions.

9 One caveat is that our probit model makes strong assumptions about the empirical representation of equation (4).

10 This difficulty spurred a major government effort to facilitate such transactions, the Home Affordable Refinance Program (http://www.makinghomeaffordable.gov/programs/lower-rates/Pages/harp.aspx). However, the initial version of this program saw limited take-up because of various unanticipated obstacles (see Dynan, 2011).

11 A household was counted as having refinanced if it reported obtaining a new mortgage since the last survey that was taken out to "refinance or roll over an earlier loan" or to "borrow additional money on [its] home equity." Mortgages reported as "modified" (less than 1 percent of the sample) were not counted, as the term "modification" is typically associated with an accommodation provided by the lender on a distressed loan and so would be expected to have different dynamics (quoted material is from the 2009 SCF codebook; http://www.federalreserve.gov/econresdata/scf/files/codebk2009p.txt).

12 Highly leveraged households appeared to have had a larger jump in precautionary needs (relative to what they have available) and, as shown in Table 4, were more likely to report that they applied for credit between 2007 and 2009. Both developments could be congruent if highly leveraged households were engaging in "precautionary borrowing"; that is, they were attempting to access credit so as to build buffers of assets in anticipation of their credit possibly being cut off in the future. 


\section{Dynan and Edelberg}

\section{REFERENCES}

Bhutta, Neil. "Mortgage Debt and Household Deleveraging: Accounting for the Decline in Mortgage Debt Using Consumer Credit Record Data." Finance and Economics Discussion Series No. 2012-14, Board of Governors of the Federal Reserve System, March 2012; http://www.federalreserve.gov/pubs/feds/2012/201214/201214pap.pdf.

Bhutta, Neil; Dokko, Jane and Shan, Hui. "The Depth of Negative Equity and Mortgage Default Decisions." Finance and Economics Discussion Series No. 2010-35, Board of Governors of the Federal Reserve System, May 2010; http://www.federalreserve.gov/pubs/feds/2010/201035/201035pap.pdf.

Bricker, Jesse; Kennickell, Arthur, B.; Moore, Kevin B. and Sabelhaus, John. “Changes in U.S. Family Finances from 2007 to 2010: Evidence from the Survey of Consumer Finances." Federal Reserve Bulletin, June 2012, 98(2), pp. 1-80; http://www.federalreserve.gov/econresdata/scf/scf 2010.htm.

Brown, Meta; Haughwout, Andrew; Lee, Donghoon and van der Klaauw, Wilbert. "The Financial Crisis at the Kitchen Table: Trends in Household Debt and Credit." Federal Reserve Bank of New York Current Issues in Economics and Finance, 2013, 19(2); http://www.newyorkfed.org/research/current issues/ci19-2.html.

Carroll, Christopher; Slacalek, Jiri and Sommer, Martin. "Dissecting Saving Dynamics: Measuring Wealth, Precautionary, and Credit Effects." IMF Working Paper No. 12/219, International Monetary Fund, September 2012; http://www.imf.org/external/pubs/ft/wp/2012/wp12219.pdf.

Casselman, Ben. "Consumers Climb Out of Debt." Wall Street Journal, December 23, 2012; http://online.wsj.com/article/SB10001424127887324731304578189361822008432.html.

Congressional Budget Office. "What Accounts for the Slow Growth of the Economy After the Recession?" November 2012; http://www.cbo.gov/sites/default/files/cbofiles/attachments/43707-SlowRecovery.pdf.

Cooper, Daniel. “U.S. Household Deleveraging: What Do the Aggregate and Household-Level Data Tell Us?” Federal Reserve Bank of Boston Public Policy Brief No. 12-2, October 11, 2012; http://www.bostonfed.org/economic/ppb/2012/ppb122.htm.

Demyanyk, Yuliya and Koepke, Matthew. "Americans Cut Their Debt." Federal Reserve Bank of Cleveland Economic Commentary, August 8, 2012; http://www.clevelandfed.org/research/commentary/2012/2012-11.cfm.

Dynan, Karen. "Playing the HARP: A New Way Forward on Housing?" UpFront (blog), Brookings Institution, October 25, 2011; http://www.brookings.edu/blogs/up-front/posts/2011/10/24-harp-housing-dynan.

Dynan, Karen. "Is a Household Debt Overhang Holding Back Consumption?" Brookings Papers on Economic Activity, Spring 2012, pp. 299-362; http://www.brookings.edu/ /media/Projects/BPEA/Spring\%202012/2012a_Dynan.pdf.

Foote, Christopher; Gerardi, Kristopher S.; Goette, Loren and Willen, Paul. "Reducing Foreclosures: No Easy Answers," in Daron Acemoglu, Kenneth Rogoff, and Michael Woodford, eds., NBER Macroeconomics Annual 2009. Chicago: University of Chicago Press, 2010, pp. 89-238.

Kennickell, Arthur B. "Tossed and Turned: Wealth Dynamics of U.S. Households 2007-2009." Finance and Economic Discussion Series Working Paper No. 2011-51, Board of Governors of the Federal Reserve System, November 7, 2011; http://www.federalreserve.gov/pubs/feds/2011/201151/201151pap.pdf.

Keys, Benjamin; Mukherjee, Tanmoy; Seru, Amit and Vig, Vikrant. “Did Securitization Lead to Lax Screening? Evidence from Subprime Loans." Quarterly Journal of Economics, February 2010, 125(1), pp. 307-62.

Mayer, Christopher; Pence, Karen and Sherlund, Shane M. "The Rise in Mortgage Defaults." Journal of Economic Perspectives, Winter 2009, 23(1), pp. 27-50.

Mian, Atif R., Rao, Kamalesh and Sufi, Amir. "Household Balance Sheets, Consumption, and the Economic Slump." June 2013, http://dx.doi.org/10.2139/ssrn.1961211.

Mishkin, Frederic S. "What Depressed the Consumer? The Household Balance Sheet and the 1973-75 Recession." Brookings Papers on Economic Activity, 1977, 9(1), pp. 123-74.

Pence, Karen M. "Comment on 'Is a Household Debt Overhang Holding Back Consumption?"' Brookings Papers on Economic Activity, Spring 2012, 1, pp. 351-58; http://www.brookings.edu/ /media/Projects/BPEA/Spring\%202012/2012a_Dynan.pdf. 


\section{Dynan and Edelberg}

Roxburgh, Charles; Lund, Susan; Daruvala, Toos; Manyika, James; Dobbs, Richard; Forn, Ramon and Croxson, Karen. "Debt and Deleveraging: Uneven Progress on the Path to Growth." McKinsey Global Institute, January 2012;

http://www.mckinsey.com/insights/mgi/research/financial markets/uneven progress on the path to growth. 